\title{
Neurofibromatosis without
} Neurofibromas: Confirmation of a Genotype-Phenotype Correlation and Implications for Genetic Testing

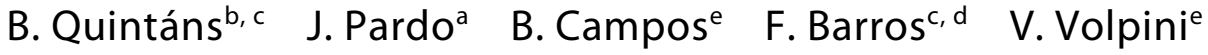 \\ Á. Carracedoc,d M.J. Sobridoc,d \\ ${ }^{a}$ Department of Neurology at ${ }^{b}$ University Clinical Hospital of Santiago de Compostela- \\ SERGAS, 'Genomic Medicine Group, University of Santiago de Compostela, Center for \\ Network Biomedical Research on Rare Diseases (CIBERER), and ${ }^{\mathrm{d}}$ Fundación Pública \\ Galega de Medicina Xenómica, Santiago de Compostela, and ${ }^{\circ}$ Center for Molecular \\ Genetic Diagnosis (CDGM), Institut d'Investigació Biomèdica de Bellvitge - IDIBELL, \\ Barcelona, Spain
}

\section{Key Words}

Neurofibromatosis · NF1 · Genotype-phenotype correlation · c.2970_2972delAAT ·

Neurofibromas · Diagnosis · De novo mutation

\begin{abstract}
Neurofibromatosis type 1 (NF1) is a multisystem disease with autosomal dominant inheritance and complete penetrance diagnosed by clinical findings. Cutaneous neurofibromas are present in almost all adult patients in the dermis, epidermis or along the peripheral nerves. Plexiform neurofibromas are subcutaneous or deep lesions involving nerve plexuses or roots. Neurofibromas can degenerate into malignant tumors, with important prognostic implications. NF1 shows a broad clinic variability even within a single family. Exceptions are cases reporting the in-frame microdeletion c.2970_2972delAAT, presenting with the typical pigmentary features of NF1, but no cutaneous or plexiform neurofibromas. We report a patient with a de novo c.2970_2972delAAT mutation who had few café-au-lait spots, only 2 of which measured $>15 \mathrm{~mm}$, axillary and submammary freckling, a flat angioma extending over the neck, arm and trunk, a high arched palate, micrognathia, macrocephaly, pes cavus and scoliosis. There was complete absence of observable cutaneous neurofibromas as well as external plexiform neurofibromas. She had had epileptic seizures since childhood; however, a diagnosis of NF1 had not been confirmed until she was 38 , partly due to the paucity of characteristic cutaneous stigmata. We confirm the association of the c.2970_2972delAAT mutation in NF1 with a particular clinical phenotype, especially with lack of detectable neurofibromas. For an appropriate management of patients and family counseling, molecular study of the NF1 gene should be considered in patients not
\end{abstract}




\begin{tabular}{c|l|l|l}
$\begin{array}{c}\text { Case Reports in } \\
\text { Neurology }\end{array}$ & $\begin{array}{l}\text { Case Rep Neurol 2011;3:86-90 } \\
\text { DOI: } 10.1159 / 000327557\end{array}$ & $\begin{array}{l}\text { Published online: } \\
\text { April 11, 2011 }\end{array}$ & $\begin{array}{l}\text { @ 2011 S. Karger AG, Basel } \\
\text { ISSN 1662-680X } \\
\text { www.karger.com/crn }\end{array}$ \\
\hline
\end{tabular}

fulfilling NIH criteria when other features suggestive of NF1 are present. In the absence of neurofibromas, starting NF1 testing with the screening of exon 17 may be worthwhile.

\section{Introduction}

Neurofibromatosis type 1 (NF1; MIM 162200) is a multisystem disease with autosomal dominant inheritance and complete penetrance. The diagnosis of NF1 is made based on clinical findings: café-au-lait (CAL) spots, skinfold freckling, neurofibromas and Lisch nodules, which are present in most patients after puberty and may be associated with other manifestations. Cutaneous neurofibromas are present in almost all patients by age 20 in the dermis, epidermis or along the peripheral nerves [1]. Plexiform neurofibromas are subcutaneous lesions with ill-defined margins that can also be located deeply within the body, involving nerve plexuses and spinal roots. Although molecular genetic analysis is available for NF1 and is useful for the diagnostic confirmation, the clinical variability sometimes extreme even within a single family - together with the lack of genotype to phenotype correlation limits the usefulness of routine genetic testing. One exception is the complete gene deletion causing severer symptoms [2]. More recently, a 3-bp in-frame deletion c.2970_2972delAAT in exon 17 was reported to correlate with pigmentary NF1 features but with no cutaneous or plexiform neurofibromas [3].

\section{Case Report}

We report a patient that had been followed up for a long time in Paediatrics, Neurology and Psychiatry departments with behavioural problems, dyslexia and epilepsy since childhood. She had had a mild psychomotor delay. She had been able to hold her head up at 7 months, to sit unaided at 17 months and to walk at 21 months. She had said the first words at 23 months and at the age of 3 she had shown mild behavioural problems. She had been delayed at school, with learning difficulties and dyslexia. Since age 2 she had been suffering from epileptic seizures, combining partial complex and generalized (atonic, tonic-clonic) seizures.

At the age of 38 years, she presented the following signs: 6 CAL spots of $10-20 \mathrm{~mm}$ ( 2 of them $>15$ $\mathrm{mm}$ ), a few other CAL spots with smaller dimensions, axillary and submammary freckling, a flat angioma extending over neck, arm and trunk (fig. 1), high arched palate, micrognathia, macrocephaly, pes cavus and scoliosis. Nerve conduction studies were normal. There was complete absence of observable cutaneous neurofibromas as well as external plexiform neurofibromas. Complete bone radiology and cardiologic evaluation were normal. No Lisch nodules were seen on eye examination. The patient's mother had multiple moles and freckles, but no other symptoms suggestive of NF1, and neither did any of the patient's sisters or her children. Specifically, the presence of optic gliomas was ruled out through ophthalmological, neuroimaging and neurophysiologic examinations. Brain and spinal cord MRI studies performed at 23, 30, 34, and 37 years of age were all normal. Axial, sagittal and coronal MRI images were acquired with a 1.5-T machine using T1-, proton density-, and T2-weighted sequences, as well as inversion-recovery sequences.

The patient had a normal 46XX karyotype. In order to screen for small rearrangements associated with cranial dysmorphism and learning delay, the Cytogenetics Whole Genome 2.7M Array (Affymetrix ${ }^{\circledR}$ ) was performed, ruling out a $22 \mathrm{q} 11$ deletion as well as alterations in $10 \mathrm{p} 13,4 \mathrm{q} 35,17 \mathrm{p} 13$ and 18q21. Genetic testing of the NF1 gene in a peripheral blood sample from this patient showed the presence of the in-frame mutation c.2970_2972delAAT, p.Met992del (NM_000267.1) in exon 17 (fig. 2). This mutation was absent in all the first-degree relatives studied, and haplotype segregation indicated that it arose de novo on the paternal chromosome (fig. 2). 


\begin{tabular}{c|l|l|l}
$\begin{array}{c}\text { Case Reports in } \\
\text { Neurology }\end{array}$ & $\begin{array}{l}\text { Case Rep Neurol 2011;3:86-90 } \\
\text { DOI: 10.1159/000327557 }\end{array}$ & $\begin{array}{l}\text { Published online: } \\
\text { April 11, 2011 }\end{array}$ & $\begin{array}{l}\text { ○ 2011 S. Karger AG, Basel } \\
\text { ISSN 1662-680X } \\
\text { www.karger.com/crn }\end{array}$ \\
\hline
\end{tabular}

\section{Discussion}

Most NF1 mutations are truncating, and missense mutations and small deletions or insertions are infrequent [4]. Other sporadic cases with the same microdeletion have been reported and its recurrence may be facilitated by the deletion of an aat looping out of a hairpin structure [3]. Our data, together with previous evidence, support the pathogenicity of the c.2970_2972delAAT mutation. It showed complete co-segregation with the disease in reported families, was not found in healthy individuals and was absent in the parents of sporadic cases [3]. Understanding the molecular mechanisms by which this mutation prevents neurofibroma formation may open up avenues for therapeutic intervention; it does not seem to affect NF1 splicing [3].

The clinical characteristics of our patient are reminiscent of other cases with the c.2970_2972delAAT mutation: CAL spots and freckles but complete absence of skin and plexiform neurofibromas. She did show, however, features reportedly less frequent in patients with this mutation compared to NF1 cohorts, such as macrocephaly and learning problems $[3,5]$.

This case confirms that the mutation c.2970_2972delAAT in NF1 is associated with a particular phenotype, especially with the absence of detectable neurofibromas. Although a complete lack of subcutaneous and plexiform neurofibromas is difficult to ascertain, an absence or reduced frequency of these lesions seem also the case in other patients with this mutation [3]. Since the burden of neurofibromas is associated with the risk of malignant nerve sheath tumours, this genotype-phenotype correlation is very useful for follow-up planning and genetic counselling. Strictly speaking, our patient did not fulfil any of the NIH criteria for NF1 $[6,7]$ except skinfold freckling. The number of CAL lesions was low, only 2 of them measuring $>15 \mathrm{~mm}$. However, a reduction in the number of CAL macules with age has been reported [8]. Thus, attention must be paid to the possibility that some NF1 mutations, such as the c.2970_2972delAAT and possibly other in-frame mutations, may present with an attenuated phenotype so that a proper NF1 diagnosis cannot be formulated according to the current diagnostic criteria.

Modifications of these criteria may be necessary to include the finding of a known pathogenic mutation. The NF1-like Legius syndrome caused by mutations in SPRED1 must also be considered in the differential diagnosis of cases with CAL spots without neurofibromas. In these cases, however, other typical NF1 features are generally also absent $[9,10]$.

The symptom combination in this patient, particularly the low burden of cutaneous manifestations, delayed the diagnosis for many years; she had 3 children before genetic confirmation was achieved. Given the importance of diagnostic confirmation not only for appropriate management of patients but also for family counselling [11], the molecular study of the NF1 gene should be considered in children with developmental delay, epilepsy, behavioural and learning disability, as well as in adults without NIH criteria but with other features in the spectrum of NF1. In the absence of neurofibromas, it may be worthwhile that the patient be screened first for the presence of the c.2970_2972delAAT mutation in exon 17. 


\begin{tabular}{c|l|l|l}
$\begin{array}{c}\text { Case Reports in } \\
\text { Neurology }\end{array}$ & $\begin{array}{l}\text { Case Rep Neurol 2011;3:86-90 } \\
\text { DOl: 10.1159/000327557 }\end{array}$ & $\begin{array}{l}\text { Published online: } \\
\text { April 11, 2011 }\end{array}$ & $\begin{array}{l}\odot \text { 2011 S. Karger AG, Basel } \\
\text { ISSN 1662-680X } \\
\text { www.karger.com/crn }\end{array}$ \\
\hline
\end{tabular}

\section{Acknowledgments}

We are thankful to the patient and her family for their kind collaboration and permission for study and report. B.Q. is supported by an agreement between the Health Service of the Galician Government (SERGAS) and the Institute of Health Carlos III (ISCIII).
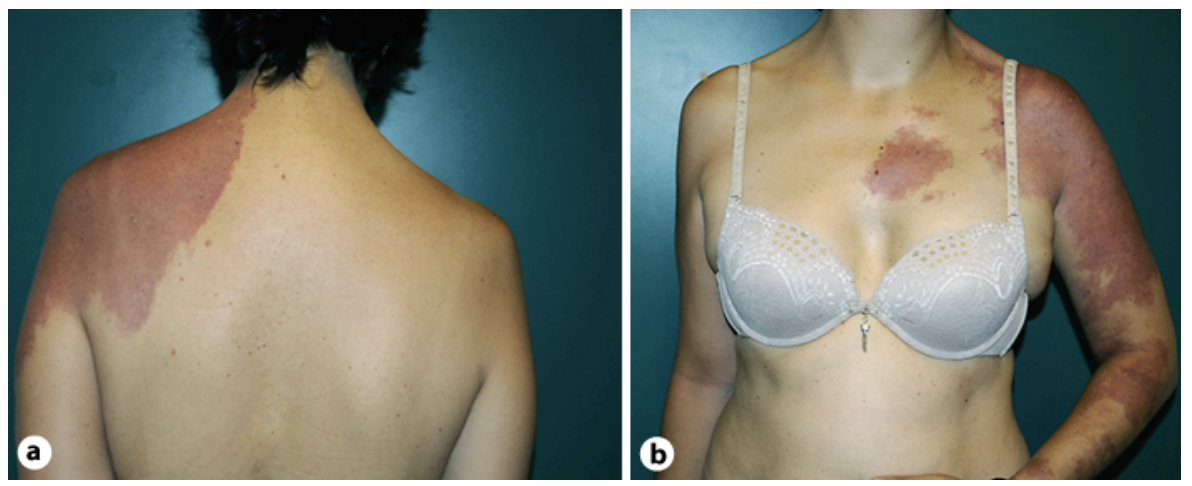

Fig. 1. Detail of the patient's back (a) and abdomen (b) showing a cervical-thoracic flat angioma, few CAL spots and absence of neurofibromas.

I

II

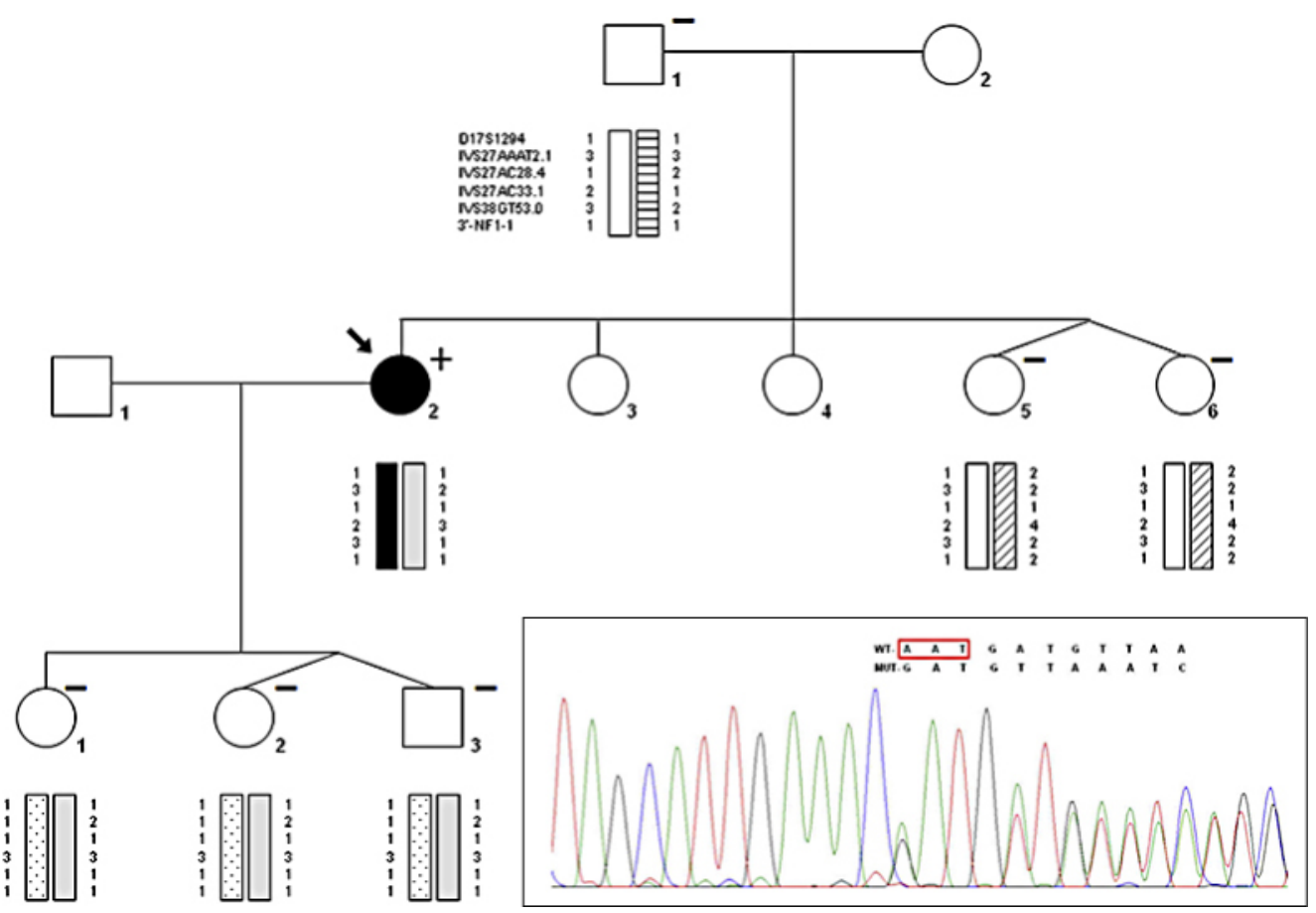

Fig. 2. Pedigree of the family showing that the mutation emerged de novo on the paternal chromosome; markers are indicated from telomere to centromere. Presence and absence of the mutation are indicated with plus and minus, respectively. Inset A fragment of the sequence of exon 17 showing the trace overlap caused by the c.2970_2972delAAT deletion in NF1. 


\begin{tabular}{c|l|l|l}
$\begin{array}{c}\text { Case Reports in } \\
\text { Neurology }\end{array}$ & $\begin{array}{l}\text { Case Rep Neurol 2011;3:86-90 } \\
\text { DOl: 10.1159/000327557 }\end{array}$ & $\begin{array}{l}\text { Published online: } \\
\text { April 11, 2011 }\end{array}$ & $\begin{array}{l}\odot \text { 2011 S. Karger AG, Basel } \\
\text { ISSN 1662-680X } \\
\text { www.karger.com/crn }\end{array}$ \\
\hline
\end{tabular}

\section{References}

1 Friedman JM, Birch PH: Type 1 neurofibromatosis: a descriptive analysis of the disorder in 1728 patients. Am J Med Genet 2007;70:138-143.

-2 Wu BL, Austin MA, Schneider GH, Boles RG, Korf BR: Deletion of the entire NF1 gene detected by the FISH: four deletion patients associated with severe manifestations. Am J Med Genet 1995;59:528-535.

-3 Upadhyaya M, Huson SM, Davies M, Thomas N, Chuzhanova N, Giovannini S, Evans DG, Howard E, Kerr B, Griffiths S, Consoli C, Side L, Adams D, Pierpont M, Hachen R, Barnicoat A, Li H, Wallace P, Van Biervliet JP, Stevenson D, Viskochil D, Baralle D, Haan E, Riccardi V, Turnpenny P, Lazaro C, Messiaen L: An absence of cutaneous neurofibromas associated with a 3-bp inframe deletion in exon 17 of the NF1 gene (c.2970-2972 delAAT): evidence of a clinically significant NF1 genotype-phenotype correlation. Am J Hum Genet 2007;80:140-151.

4 Fahsold R, Hoffmeyer S, Mischung C, Gille C, Ehlers C, Kücükceylan N, Abdel-Nour M, Gewies A, Peters H, Kaufmann D, Buske A, Tinschert S, Nürnberg P: Minor lesion mutational spectrum of the entire NF1 gene does not explain its high mutability but points to a functional domain upstream of the GAP-related domain. Am J Hum Genet 2000;66:790-818.

5 Hachon C, Iannuzzi S, Chaix Y: Behavioural and cognitive phenotypes in children with neurofibromatosis type 1 (NF1): The link with the neurobiological level. Brain Dev 2010;33:52-61.

-6 Gutmann DH, Aylsworth A, Carey JC, Korf B, Marks J, Pyeritz RE, Rubenstein A, Viskochil D: The diagnostic evaluation and multidisciplinary management of neurofibromatosis 1 and neurofibromatosis 2. JAMA 1997;278:51-57.

7 National Institutes of Health Consensus Development Conference Statement: Neurofibromatosis. Bethesda, Md., USA, July 13-15, 1987. Neurofibromatosis 1988;1:172-178.

-8 Khosrotehrani K, Bastuji-Garin S, Zeller J, Revuz J, Wolkenstein P: Clinical risk factors for mortality in patients with neurofibromatosis 1: a cohort study of 378 patients. Arch Dermatol 2003;139:187-191.

-9 Brems H, Chmara M, Sahbatou M, Denayer E, Taniguchi K, Kato R, Somers R, Messiaen L, De Schepper S, Fryns JP, Cools J, Marynen P, Thomas G, Yoshimura A, Legius E: Germline loss-of-function mutations in SPRED1 cause a neurofibromatosis 1-like phenotype. Nat Genet 2007;39:1120-1126.

10 Messiaen L, Yao S, Brems H, Callens T, Sathienkijkanchai A, Denayer E, Spencer E, Arn P, BabovicVuksanovic D, Bay C, Bobele G, Cohen BH, Escobar L, Eunpu D, Grebe T, Greenstein R, Hachen R, Irons M, Kronn D, Lemire E, Leppig K, Lim C, McDonald M, Narayanan V, Pearn A, Pedersen R, Powell B, Shapiro LR, Skidmore D, Tegay D, Thiese H, Zackai EH, Vijzelaar R, Taniguchi K, Ayada T, Okamoto F, Yoshimura A, Parret A, Korf B, Legius E: Clinical and mutational spectrum of neurofibromatosis type 1-like syndrome. JAMA 2009;302:2111-2118.

11 Radtke HB, Sebold CD, Allison C, Haidle JL, Schneider G: Neurofibromatosis type 1 in genetic counseling practice: recommendations of the National Society of Genetic Counselors. J Genet Couns 2007;16:387-407. 